\title{
Simulations CAE of wood pellet machine
}

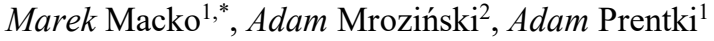 \\ ${ }^{1}$ Faculty of Mathematics, Physics \& Technical Science, Kazimierz Wielki University in Bydgoszcz, Poland \\ ${ }^{2}$ Faculty of Mechanical Engineering, University of Technology and Life Sciences in Bydgoszcz, Poland
}

\begin{abstract}
The work presents the problems of pellet production, and special attention is paid to the issues of pellet machine construction. A sample of CFD application, SolidWorks Flow Simulation, was used to analysis the flow and compaction of wood material. Examples of speed distributions inside the feed hopper and in the working system are presented.
\end{abstract}

Keywords: CAD/CAE, pellet, CFD

\section{Introduction}

The EU produces about $50 \%$ of world production of wood pellets. However, the demand for pellets in the EU alone accounts for $75 \%$ of the market wood pellets in the world. Therefore, the EU is the largest market of wood pellets in the world, with about 20.5 million tons of pellets consumed in the same 2015. The total consumption of 2015 approx. $65 \%$ of the volume of all the pellets were used to produce heat and $35 \%$ for energy production. Despite the significant production of pellets, the Scandinavian countries, mainly Denmark and Sweden, partly depend on imports from countries in the Baltic Sea region and Russia. The restrictions imposed on ports in Scandinavia are much more advantageous for the countries of the Baltic Sea. These countries usually use smaller vessels to transport pellets, compared to larger transporters used in trade across the Atlantic. In Denmark, one recipient of pellets, is located by the sea, in a much deeper place than the others, through which trade across the Atlantic is facilitated. Other places in Scandinavia often do not have such favourable conditions. However, it is anticipated that the growing infrastructure flexibility and upcoming port upgrades will facilitate trade with North America in the near future $[1,2]$.

In turn, the pellet market in Germany and Austria, and to a lesser extent in France and Italy is more isolated and depends mainly on the production of pellets in their own regions. Since 2008, the demand for wood pellets has started to exceed the production capacity in many countries. Import has become a necessity [2].

The production of wood pellets in the EU member states in 2012 amounted to 10.5 million tonnes (9.5 million tonnes in 2011), which means that the imports to the Union amounted to about $30 \%$ of total consumption. The four main producers in the EU are

\footnotetext{
${ }^{*}$ Corresponding author: mackomar@ukw.edu.pl

Reviewers: Krzysztof Talaśka, Milan Žmindák
} 
Germany (2.2 million tonnes), Sweden (1.2 million tonnes), Latvia (1 million tonnes) and Austria (0.9 million tonnes). The top ten pellet producers also include Poland [3-5].

The Polish pellet market has started to develop significantly since 2003. It is a relatively young market compared to Western countries such as Austria, Sweden or Germany, which already have their own quality standards. Initially, the majority of pellets produced in Poland were exported, however, with the increase in the popularity of granules, it was also burnt in our country [4,5]. Over the past few years, a comprehensive infrastructure connected with the pellet market has been created in Poland: there are specialized vehicles transporting fuel, tanks and silos for its storage as well as modern, automatic heating furnaces. Recent estimates for 2013 indicate that about 600,000 are produced in Poland. tons of pellets, while it comes down to about 400 tons. The Polish pellet market with around 1 million tonnes of pellets is one of the most prominent in Europe [5].

Pellets were initially mainly produced from wood waste. The best quality of pellets is the one that has the least amount of moisture. This causes that sawdust is harder to access and their price increases. Therefore, alternative raw materials are being sought for its production. They found application among others materials such as wood chips, rape straw, wheat straw, etc. [6-8]. Currently, analyzes are made to determine the suitability of energy plants for the production of pellets. The introduction of energy plants for the production of pellets is not to fast. This is due to the fact that pellets from these plants have a low calorific value and high ash content in relation to wood sawdust granules. An important advantage of pellets is that they can be produced from locally available raw materials. It gives the opportunity to create new jobs. The granulate is produced from wood waste, so its production contributes to reducing the problem of waste management and the consumption of fossil fuels. Pellets from wood waste is competitive for oil and coal economically and due to lower gas and dust emissions during combustion.

\section{Characteristics of the pelleting process}

The relationship between the basic parameters of the pellet granulation process is described by formula 1 . The optimal combination of geometric matrix relationships: $d /(L+2 \cdot l)$ allows to obtain the desired final product $[3,4,5]$ :

$$
R=\mu \cdot P \cdot d \cdot l<|K|
$$

where:

$R$ - friction $[\mathrm{N}]$,

$\mu$ - coefficient of friction,

$P$ - pressure exerted on the surface of the hole in the matrix $\left[\mathrm{N} / \mathrm{m}^{2}\right]$,

$d$-diameter of the hole in the matrix [m],

$l-$ length of the hole in the matrix,

$K-$ press force $[\mathrm{N}]$.

Pelleting process may be used an annular or flat die. Usually it is preceded by grinding, thanks to which an appropriate degree of material disintegration is obtained [9-14]. In any case, the biomass is fed into the drum, wherein one or more press rollers are pressed to the cylindrical holes of the matrix. Template in both cases can of course be replaced, which allows to change the diameter of the cylindrical holes, and thus the production of pellets of various sizes. Biomass pressing increases its temperature. The level of pressure in the matrix to be adjusted, inter alia, to the type of granular biomass.

The flat die holder eliminates the dangers of high rotational speeds and high torques that occur in the case of annular die. The low speed of the receiving shaft prevents vibration. In the compaction chambers of flat pelletts, there are no spatial restrictions that occur in the rings. We can use large diameters of thickening rolls, which translates into the use of large 
bearings, and we can apply various types of design improvements that are sometimes necessary for the pelleting process, such as sprinklers, steam extractors, etc. Replacement of consumables is much simpler, the cost of replacements is definitely lower. In addition, the lubrication system is simpler, it does not require the use of precise equipment that occurs in ring granulators. In fact, the service life of consumables is slightly shorter than in the case of ring granulators, but their price and simplicity of assembly equates the balance of profits and losses. The most important aspect in support of flat pelletizers is the property of obtaining significantly higher pressures per unit area of the die, so we can already carry out the pelleting process without using binders with straw and sawdust even with a pellet machine with a $15 \mathrm{~kW}$ motor [6].

Pellet machines with a ring matrix are made in a moving matrix system or with moving rollers. Selected examples of construction solutions of this type are presented in Fig. 1.
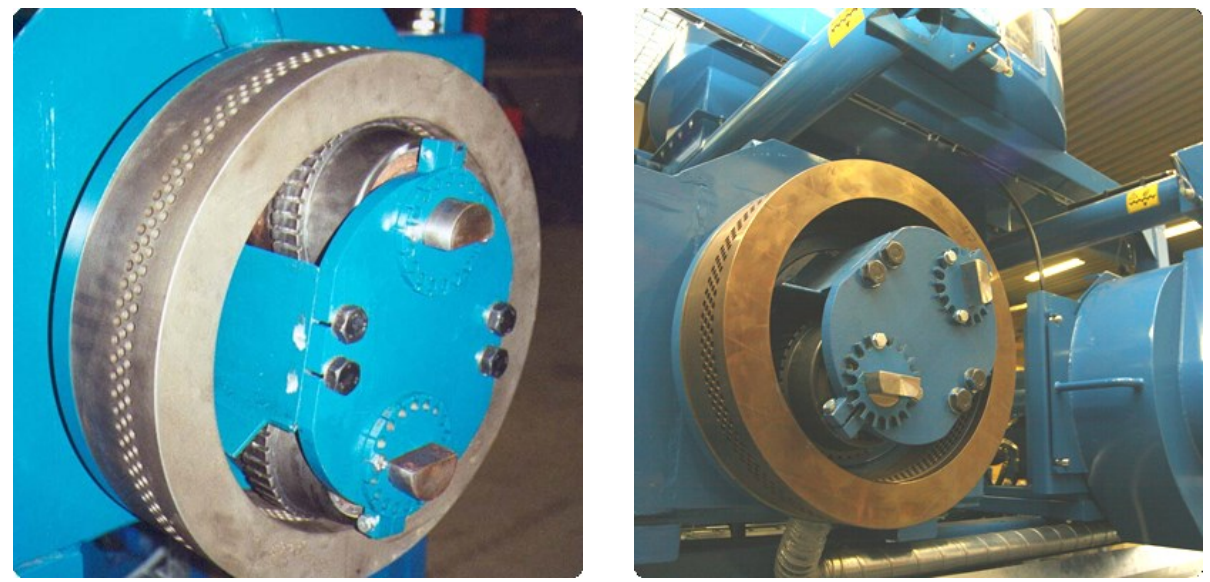

Fig. 1. Examples of elements - rollers and dies for rotary pellettres with an annular matrix [16]

\section{Optimization of pelleting machine construction}

The working system is based on the pellet-ring concept with a ring matrix. It consists of a matrix and two rollers (Fig. 2). The operation of the working mechanism consists in centrifugal pressing on the inner surface of the die by means of a set of rollers. The working system is driven by a $30 \mathrm{~kW}$ motor and a rotational speed of $1500 \mathrm{rpm}$. The rotational speed is transmitted from the engine to the system by means of two gear transmissions. The moment of force is transmitted by means of a claw coupling. The thickness of the die is $120 \mathrm{~mm}$, the outer diameter is $425 \mathrm{~mm}$, the width is $142 \mathrm{~mm}$, and the diameter of the holes in the matrix is $8 \mathrm{~mm}$. The diameter of the rollers is $127 \mathrm{~mm}$, and their width is $102 \mathrm{~mm}$. Optimally made work system ensures high durability of the device [12]. 


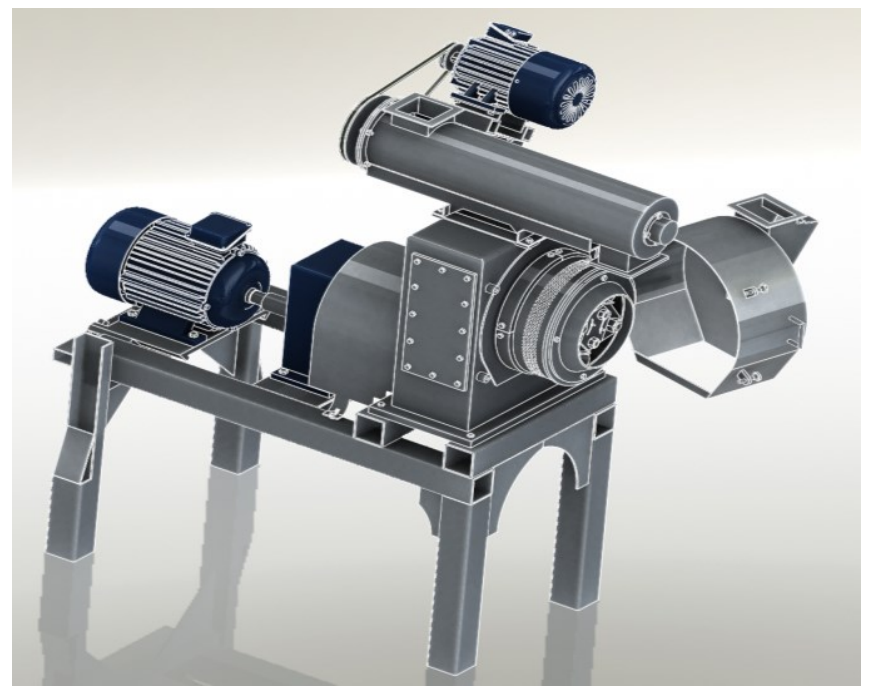

Fig. 2. Design of a pellet machine by the Alchemik JP company - 3D SolidWorks visualization [6]

The pellet production technology in the rotary pelleting system with the annular matrix requires appropriate fragmentation, quality and humidity of the material as well as the right proportions of ingredients subjected to granulation. Rings of pellet machine are characterized by high quality and durability of the matrix (hardened stainless steel) and rolls. The device includes a conditioner, feed screw feeder and granulator. The efficiency of this type of equipment depends on the type and quality of raw material and strict adherence to production technology. The raw material is taken to the conditioner chamber where it is evaporated (unified in terms of humidity) with steam coming from the steam generator and mixed. It is recommended, however, that in the production of fuel pellets from straw and sawdust, the raw materials are pre-mixed with a binder before filling into the conditioner. In the conditioner, the mixing process can be repeated. The raw material thus prepared is uniformly fed to the granulator where it is forced through the mesh of the die under the pressure of the rolls. The obtained pellets should be subjected to a cooling process.

CAE methods are increasingly widespread in the field of structure optimization. In many cases, finite element methods are used. These include the determination of damage prediction [15-18]. Optimization also applies to the determination of dynamics parameters, e.g. Constructing Surface Mining Machinery and vertical vehicle non-stationary random vibrations [19-21]. Computer methods are also successfully used for design verification and for determining vibro-acoustic parameters of gears, machine drives [22-25]. To analyze the granulation and agglomeration aspects, the SolidWorks Flow Simulation module was used. It is a module dedicated to the analysis of fluid mechanics (CFD). The tool allows to perform simulations of fluid flow, advanced thermal analyzes, heat transfer analyzes between the designed components and a predefined medium, check the thermal comfort of residential buildings (HVAC) and carry out specialized simulations of cooling electronic components. This is the second tool next to the SolidWorks simulation add-on that allows for effective validation and optimization of the designed products. In addition to the analysis and simulation of CFD (Computational Fluid Dynamics), gas flows, the program can create transparent simulations in the form of visualization.

In the pellet production process, it is important to properly thicken the material before compacting. It consists, among others, in adjusting the speed of movement of material intended for agglomeration. The figure below shows the symbolic distribution of wood pulp 
granules in the working drum and the range of speed of movement when moving from the feeding screw.
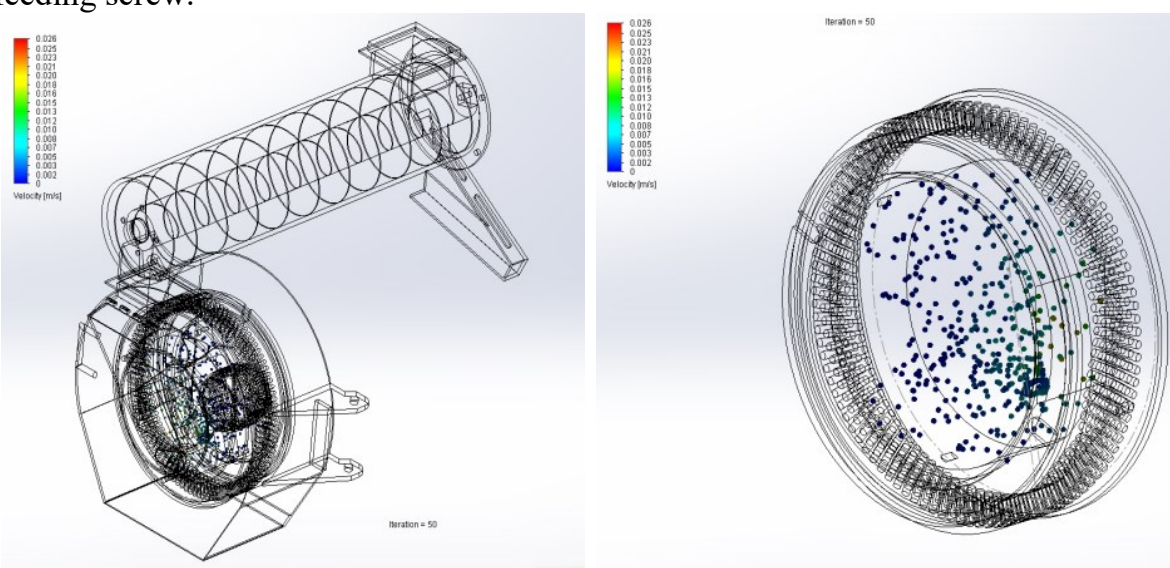

Fig. 3. Examples distribution of wood pulp granules in the working drum and the range of speed of movement when moving from the feeding screw SolidWorks Flow Simulation)

On the basis of the speed granule distribution, it can be seen that there is a significant increase in sawdust mass velocity moving towards the cylindrical holes. This is due to the effect of centrifugal force and material movement according to the designated direction. Initial compaction of the material takes place earlier than in the working system of the pellet machine. In the screw feeder, the material is compacted in transport spaces during the process (Fig. 4).
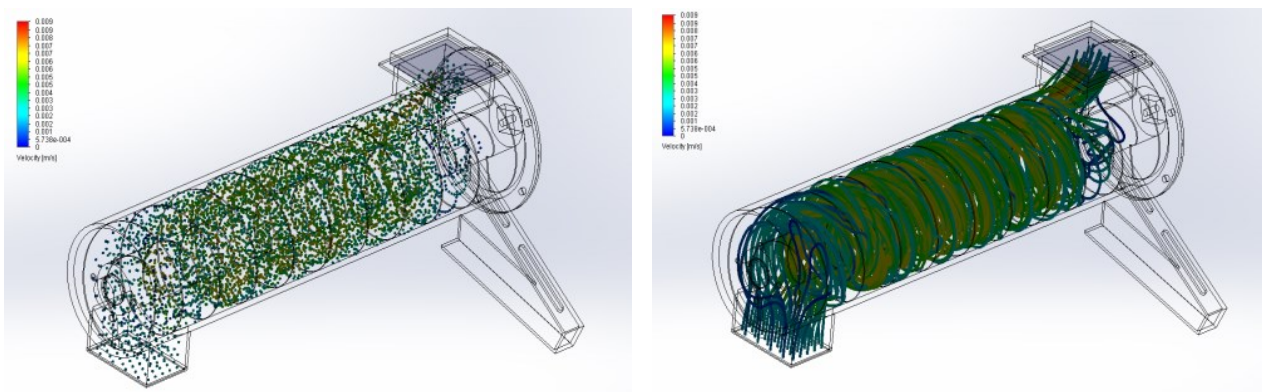

Fig. 4. Model representation of transporting and compaction of wood material before the stage of proper compaction with presentation of the speed gradient (SolidWorks Flow Simulation)

On the basis of the simulation, a slight increase in pressure at the inlet to the worm conveyor system and the screw surface can be noticed. Obtaining more detailed simulation results would require operation in the context of matter and homogenization in the worm feed system, and mass transfer. One should consider for this purpose, for example, the implementation of an application for plastic injection analysis, in addition the use of a material model with particle mass parameters. At this stage, all elements that do not participate directly in the simulation process should be immobilized. Inconvenience may also be the fact that the model should be limited to one inlet and one outlet, and the construction system should be simplified for calculations. 


\section{Summary}

The process of pelleting is a high-energy process (energy consumption of the process depending on the material processed can range from approx. 10-15 to approx. 80-100 kWh/t.) Working systems "matrix-compacting rollers" pelleting equipment wear out after a short period of work (about $1 / 10$ to $1 / 15$ of the lifetime of the whole device). During the CFD simulation based on SolidWorks Flow Simulation of the pellet machine, the following factors are important for the successful course of granulation in pellets - and thus for obtaining a high quality of the final product: the quality of the raw material used for production, performance of the granulating machine and the course of the granulation process, friction in the matrix, surface and material from which the matrix and press are made, length and diameter of holes in the matrix, the thickness of the biomass material that is subjected to the pressure of the rollers on the surface of the die - the thickness of the material layer reaching the die holes, compression frequency - the speed at which the press roll moves.

\section{References}

1. USDA Foreign Agricultural Service. 2016. EU-28. Biofuels Annual. EU Biofuel Annual (2016)

2. www.forest-monitor.com/pl/ue-rynek-pellet-drzewnych - 05 (2017)

3. J. Jakś, A. Piotrowski, P. Piotrowski, Instalacje do wytwarzania brykietu i pelletu. Rozdział w monografii pt. V Eko-Euro-Energia Inżynieria Odnawialnych Źródeł Energii pod redakcją A. Mrozińskiego, Wydawnictwo Fundacji Rozwoju Mechatroniki, ISBN 978-83-932977-6-4, s. 55-71, Bydgoszcz (2012)

4. R. Hejft, Ciśnieniowa aglomeracja materiałów roślinnych. Politechnika Białostocka, Białystok (2002)

5. R. Hejft, Pelletowanie i brykietowanie $w$ urzadzeniach o niewielkiej wydajności. Czysta energia 06 (2008)

6. BZ - 96/2012/WIM „Prace rozwojowe w zakresie opracowania i optymalizacji konstrukcji pelleciarki do wytwarzania pelletu (Realizowany w ramach „Programu pilotażowego w województwie kujawsko-pomorskim Voucher badawczy” $\mathrm{VB} / 02 / 2012 / 25)$

7. A. Janewicz, B. Kosturkiewicz, Brykietowanie węgla brunatnego z biomasa w celu uzyskania paliwa kompozytowego. Rynek Energii, 5, p.121-128 (2014)

8. B. Kosturkiewicz, A. Janewicz, A. Magdziarz, Results of briquetting and combustion process on binder- free coking coal. Pol. J. of Env. Stud. 4/23, p. 1385-1389 (2014)

9. J.M. Czerniak, M. Macko, D. Ewald, The CutMAG as a new hybrid method for multiedge grinder design optimisation. Advances in Intelligent Systems and Computing. Vol. 401, p. 327-337 (2016)

10. J. Flizikowski, A. Mroziński, A. Tomporowski, Active monitoring as cognitive control of grinders design. AIP Conference Proceedings 1822, 020006 (2017)

11. M. Macko, K. Tyszczuk, G. Śmigielski, J. Flizikowski, A. Mroziński, Utility of an unitary-shredding method to evaluate the conditions and selection of constructional features during grinding, MATEC, 157, 05016, Web of Conferences (2018)

12. J. Flizikowski, M. Macko, J. Czerniak, A. Mroziński, Implementation of genetic algorithms into development of mechatronic multi-edge's grinder design, ASME 2011 International Mechanical Engineering Congress and Exposition, IMECE (2011)

13. M. Macko, J. Flizikowski, The method of the selection of comminution design for nonbrittle materials, AIChE Annual Meeting, Conference Proceedings (2010) 
14. J. Flizikowski, M. Macko, Method of estimation of efficiency of quasi-cutting of recycled opto-telecommunication pipes, 46(1), pp. 53-59, Polimery/Polymers (2001)

15. M. Saga, M. Vasko, P. Pechač, Chosen Numerical Algorithms for Interval Finite Element Analysis, Procedia Engineering, vol. 96 (2014)

16. M. Vaško, M. Sága, Application of Fuzzy Structural Analysis for Damage Prediction Considering Uncertain S/N Curve, Applied Mechanics and Materials, Vol. 420, pp. 21-29 (2013)

17. P. Pechač, M. Saga, Controlling of Local search Methods' Parameters in Memetic Algorithms Using the Principles of Simulated Annealing, Procedia Engineering, vol. 136 (2016)

18. E. Rusiński, P. Moczko, D. Pietrusiak, G. Przybyłek, Experimental and numerical studies of jaw crusher supporting structure fatigue failure, Strojniški vestnik - Journal of Mechanical Engineering 59, 09 (2013)

19. E. Rusiński, J. Czmochowski, D. Pietrusiak, Selected Problems in Designing and Constructing Surface Mining Machinery. FME Transactions (2012) 40, vol. 40, No 4, (2012)

20. M. Sága, L. Jakubovičová, Simulation of vertical vehicle non-stationary random vibrations considering various speeds. Scient. J. of Siles. Univ. of Techn. - Series Transport 84, 113-118 (2014)

21. A. Sapietová, M. Sága, I. Kuric et al., Application of optimization algorithms for robot systems designing. Int. J. of Adv. Rob. Syst. 15/1 (2018)

22. P. Krawiec, A. Marlewski, Profile design of noncircular belt pulleys, Journal of Theoretical and Applied Mechanics, Vol. 54, No. 2, pp. 561-570 (2016)

23. P. Krawiec, A. Marlewski, Spline description of non-typical gears for belt transmissions, J. of Theoret. and Appl. Mech., Vol. 49 No 2, pp. 355-367 (2011)

24. J. Iwaniec, M. Iwaniec, Output-only identification of vibratory machine suspension parameters under exploitational conditions. Solid State Phenom. 12th Conference on Active Noise and Vibration Control Methods, MARDiH 2015; Krakow. Vol. 248, p. 175-185 (2016)

25. M. Iwaniec, The influence of constructional parameters on stiffened plates sound radiation. Arch. of Acoust. Open Access, Vol. 30, Issue 4, p. 483-494 (2005) 